\title{
Role of Trace Constituent in Ground Water Quality in Nine Tribal Block of Madhya Pradesh, India
}

\author{
Satyendra Thakur*, M.K. Awasthi, R.K. Nema and Sarita Dubey
}

Department of Soil and Water Engineering, College of Agricultural Engineering, Jawaharlal Nehru Krishi Vishwa Vidyalaya, Jabalpur (M.P), India

*Corresponding author

\section{A B S T R A C T}

Keywords

Ground water quality, Drinking and

Irrigation water, Trace constituents

Article Info

Accepted:

16 December 2017

Available Online:

10 January 2018
A study was carried out in selected blocks to assess the ground water quality in nine blocks in tribal districts of Madhya Pradesh. The various trace constituents (zinc, copper, cadmium, lead, nickel, manganese and chromium) were analyzed in at ground water quality in open well. The results were compared with standard permissible limits of BIS, Royal Irrigation Department and FAO which show all ground water samples of study area in 2013-14 were fall in "good to permissible limit" category and suitable for drinking and irrigation purpose. In this study, these entire elements were found within desirable limit.

\section{Introduction}

Ground water is the principal source of drinking water in our country and indispensable source of our life. The problem of ground water quality is acute. Groundwater is particularly important as it accounts for 88 $\%$ of the drinking water in rural areas (Kumar, 2004). The quality is the function of the physical, chemical and biological parameters, and could be subjective as it depends on a particular intended use (Tatawat et al., 2008). Water is also essential raw material for photosynthesis and therefore it is important for crop production (Smitha et al., 2007). Almost $70 \%$ of water in India has become polluted due to the discharges of domestic sewage and industrial effluents in to natural water sources (Radhakrishan et al., 2007).

Its development and management plays a vital role in agriculture production, for poverty reduction, environmental sustenance and sustainable economic development. In some areas of the world, people face serious water shortage because groundwater is used faster than it is naturally replenished. Human development and population growth exert many and diverse pressures on the quality and the quantity of water resources and on the access to them. Water quality monitoring and assessment is the foundation of water quality 
management; thus, there has been an increasing demand for monitoring water quality of many rivers and ground water by regular measurements of various water quality variables (Bartram and Balance, 1996; Hirsch et al., 1991).

Long term waste water irrigation may lead to the accumulation of heavy metals in agricultural soils and plants. Food safety issues and potential health risks make this as one of the most serious environmental concerns (Cui et al., 2004). Vegetables accumulate heavy metals in their edible and non-edible parts. Although some of the heavy metals such as $\mathrm{Zn}, \mathrm{Mn}, \mathrm{Ni}$ and $\mathrm{Cu}$ act as micro-nutrients at lower concentrations, they become toxic at higher concentrations. Health risk due to heavy metal contamination of soil has been widely reported (Eriyamremu et al., 2005; Muchuweti et al., 2006; Satarug et al., 2000). Crops and vegetables grown in soils contaminated with heavy metals have greater accumulation of heavy metals than those grown in uncontaminated soil (Marshall et al., 2007; Sharma et al., 2006, 2007). Whereas in the present study samplings were done throughout the year and test the ground water quality for health risk was ascertained through calculation of different hazard quotients.

\section{Materials and Methods}

Water samples were collected as per standard method of sampling techniques, for the year 2013.There were seventy nine samples from selected location. Collection was made from nine blocks such as - Kundam, Bajag and Karanjia, Mohgaon and Bichhia, Chhappra, Kurai, Keolari and Ghansore from districts of Madhya Pradesh- Jabalpur, Dindori, Mandla and Seoni. Composite sample was stored in non-reactive plastic bottles. Plastic bottles of 1 liter capacity with stopper were used for collecting samples. Each bottle was washed with $2 \%$ Nitric acid and then rinsed three times with distilled water. The bottles were then preserved in a clean place. The bottles were filled leaving no air space, and then the bottle was sealed to prevent any leakage. Each container was clearly marked with the name and date of sampling. Groundwater samples were collected between 8 am to $11.00 \mathrm{am}$. Open well samples was collected from nine blocks location.

\section{Results and Discussion}

\section{Trace constituents; $\mathrm{Zn}, \mathrm{Cu}, \mathrm{Cd}, \mathrm{Pb}, \mathrm{Ni}, \mathrm{Mn}$ and $\mathrm{Cr}$}

Zinc is an important micronutrient for the crop production. Concentration of Zinc in small quantity in irrigation water is beneficial to the crop. The concentration of Zinc was found in ground water samples obtained from Mohgaon, Keolari, Bichhia and Kundam blocks was (0.0086, 0.0066, 0.006 and 0.0032 ppm) respectively (Fig. 1). The standard for irrigation water approved by BIS (Bureau of Indian Standards) for $\mathrm{Zn}$ is $5.0 \mathrm{ppm}$.

These results show that Zinc deficiency in ground water but Zinc toxic to many plants at widely varying concentration, reduced toxicity at increased $\mathrm{pH}$ (6 or above) and in fine textured or organic soils (Ayers and Westcot 1985). The contamination of all ground water samples of Zinc concentration fall under permissible limit.

The desirable limit for copper is $0.05 \mathrm{ppm}$ and the permissible limit in the irrigation water is $0.20 \mathrm{ppm}$ by FAO. The undesirable effect beyond the desirable limit is astringent taste, discoloration and corrosion of pipes, fittings and utensils will be caused. During the observation period of the year 2013, copper was not present in ground water samples except sample obtained from Bajag, Bichhia and Keolari blocks (0.001, 0.0022 and 0.0003 ppm) respectively (Fig. 2). 
The desirable limit for cadmium is $0.03 \mathrm{ppm}$ by Royal Irrigation Department. Beyond this the water becomes toxic. Toxic to beans, beets and turnips at a concentration below $0.1 \mathrm{ppm}$. The cadmium was found ranging from 0.015 , $0.014,0.0133,0.0131,0.0115,0.0113,0.0103$, 0.009, 0.007 ppm (Fig. 3) in ground water samples obtained from Ghansore, Kundam, Keolari, Karanjia, Mohgaon, Bajag, Kurai, Bichhia, Chhappra blocks respectively. However, concentration of $\mathrm{Cd}$ is very low but very harmful for human consumption.

$\mathrm{Cr}, \mathrm{Ni}, \mathrm{Cd}$ and $\mathrm{Pb}$ these are also called as Heavy metals. Heavy metals are very harmful for crop as well as human body. The permissible limit for chromium is $0.1 \mathrm{ppm}$ as per the Royal irrigation Department. During the observation period of the year 2013, Concentration of $\mathrm{Cr}$ was found in very less amount and maximum concentration was recorded Mohgaon, Chhappra and Keolari blocks $(0.094,0.091$ and $0.051 \mathrm{ppm})$ but within permissible limit (Fig. 4).

The recommended maximum limit for nickel is $0.2 \mathrm{ppm}$ as per the Royal Irrigation Department. Nickel is toxic to a number of plants at 0.5 to $1.0 \mathrm{ppm}$, and reduced toxicity at neutral or alkaline $\mathrm{pH}$ (Ayers and Westcot 1985). Very little concentration of nickel observed in ground water samples obtained from different location of study area during year 2013 as shown in Figure 5.

Fig.1 Block wise concentration of $\mathrm{Zn}$ - present values

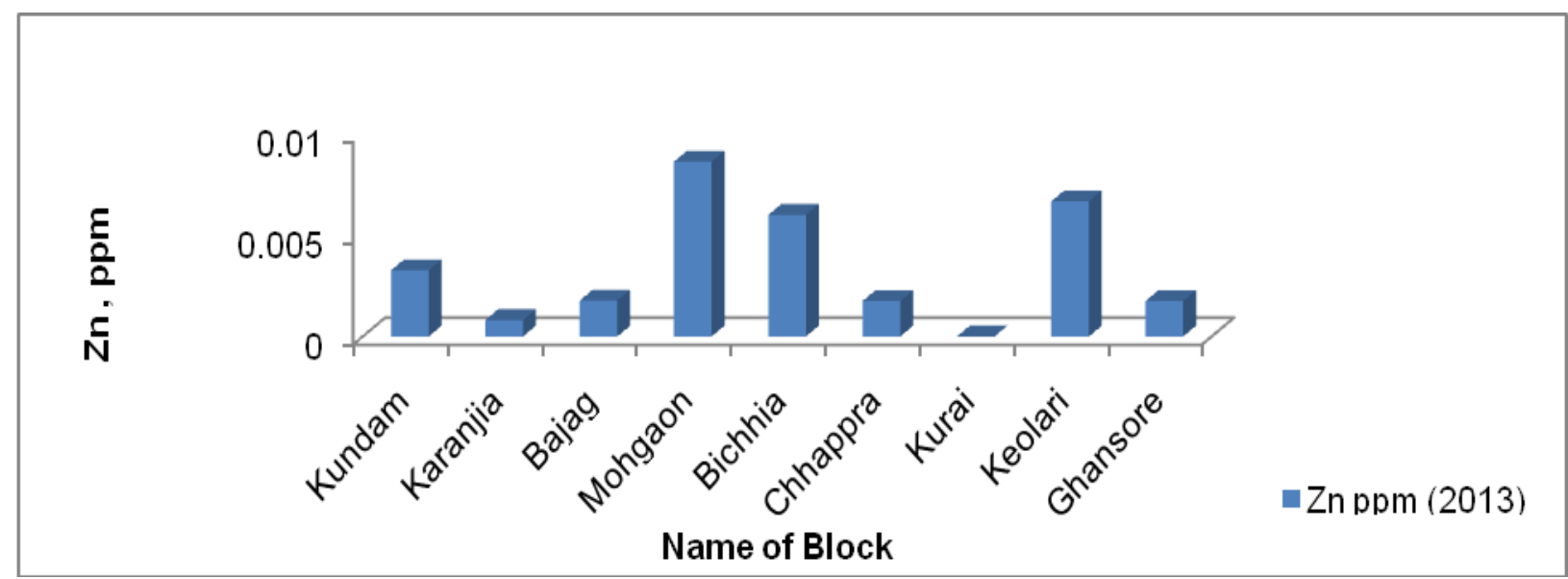

Fig.2 Block wise concentration of $\mathrm{Cu}$ - present values

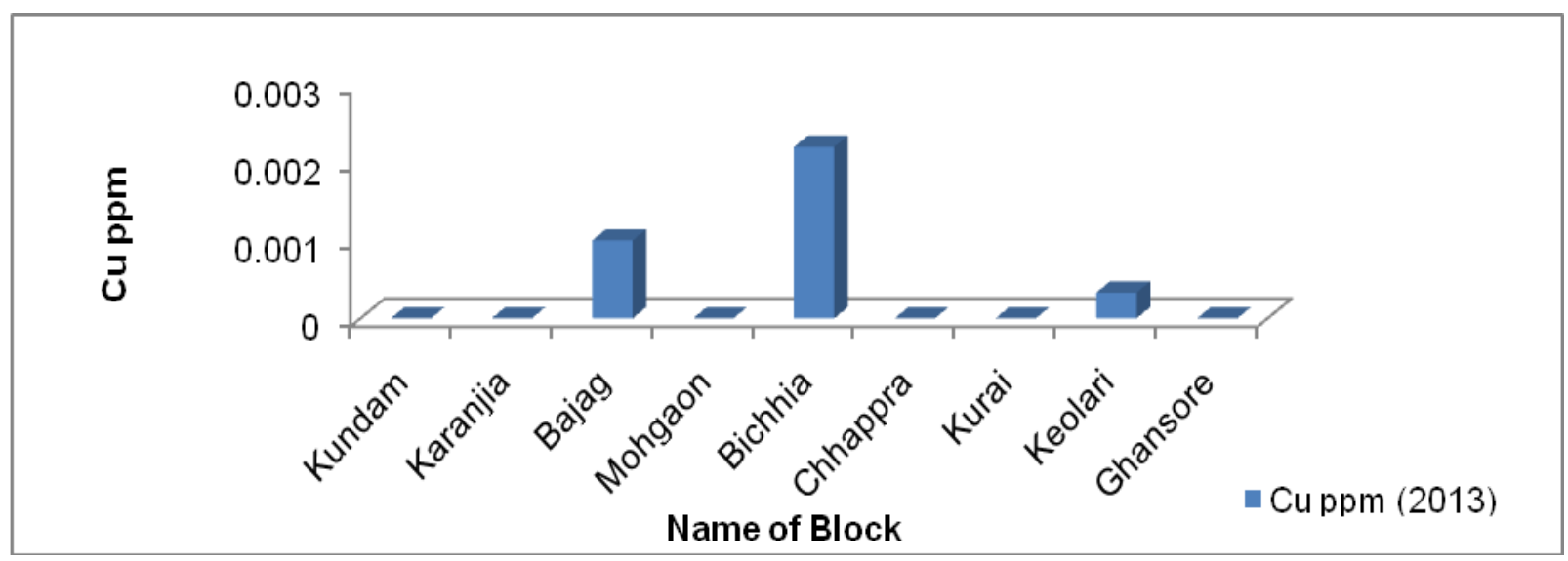


Fig.3 Block wise concentration of $\mathrm{Cd}$ - present values

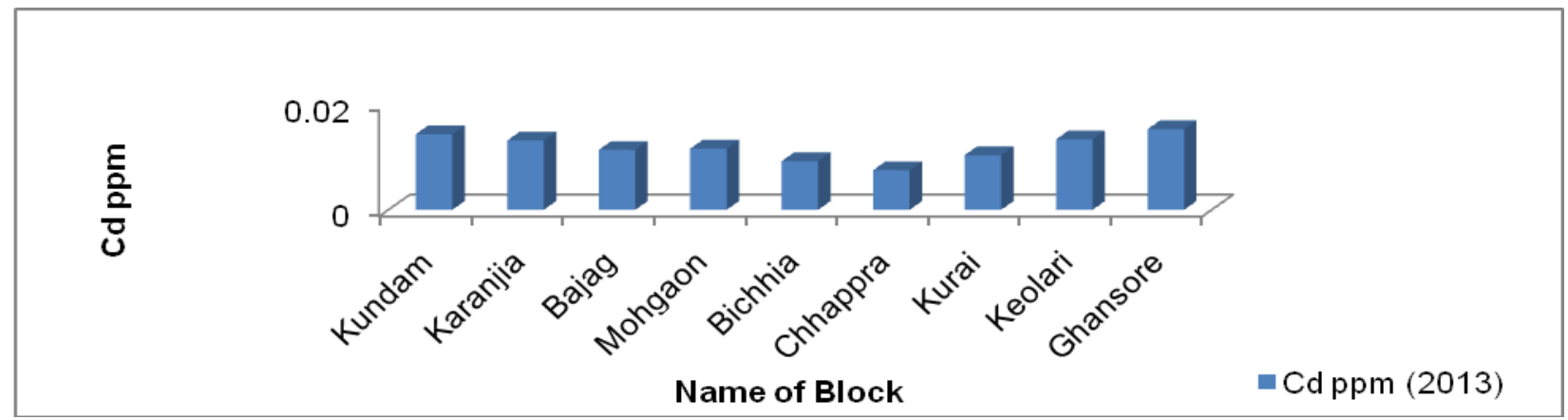

Fig.4 Block wise concentration of $\mathrm{Cr}$ - present values

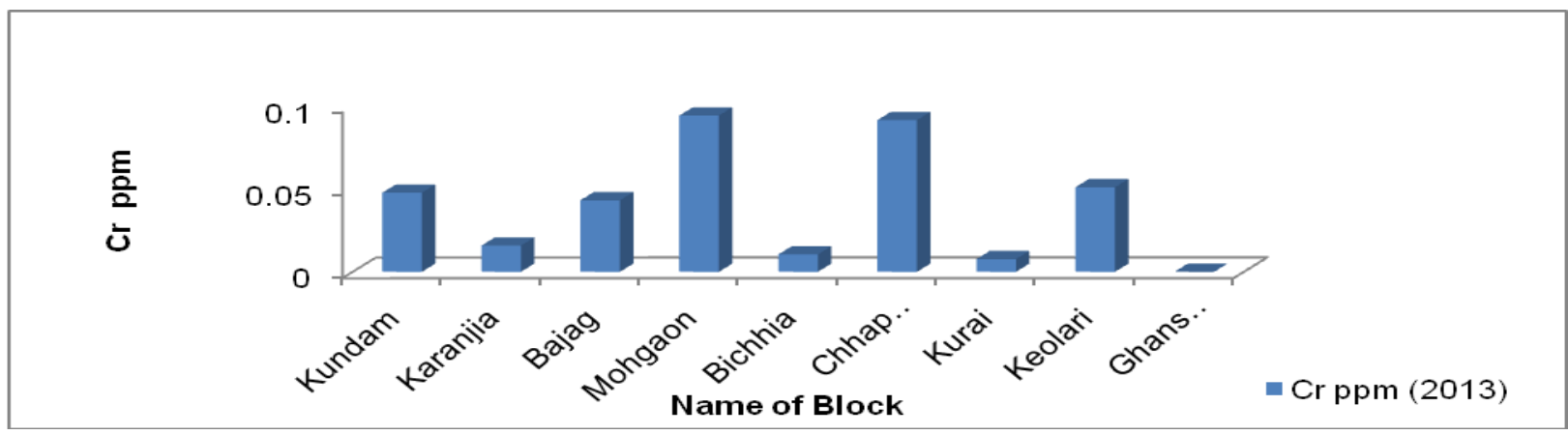

Fig.5 Block wise concentration of $\mathrm{Ni}$ - present values

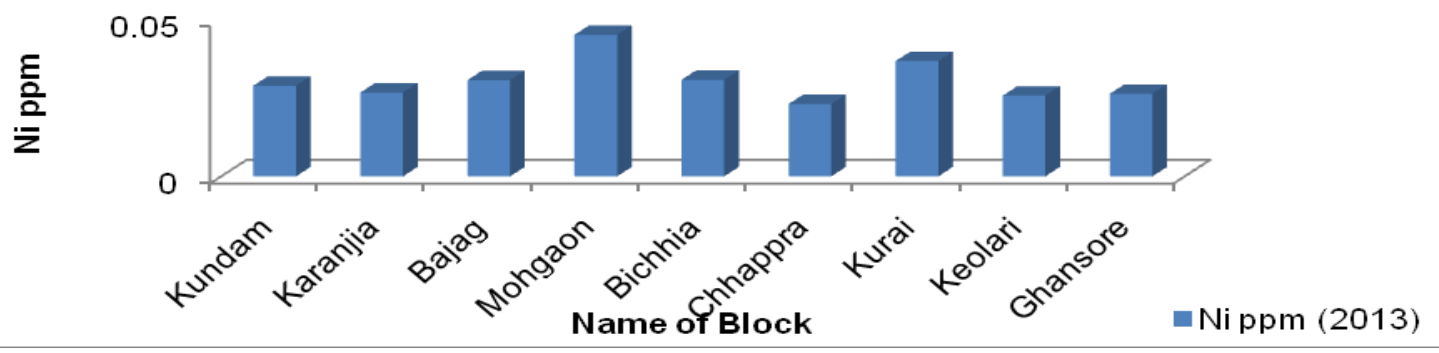

Fig.6 Block wise concentration of Mn - present values

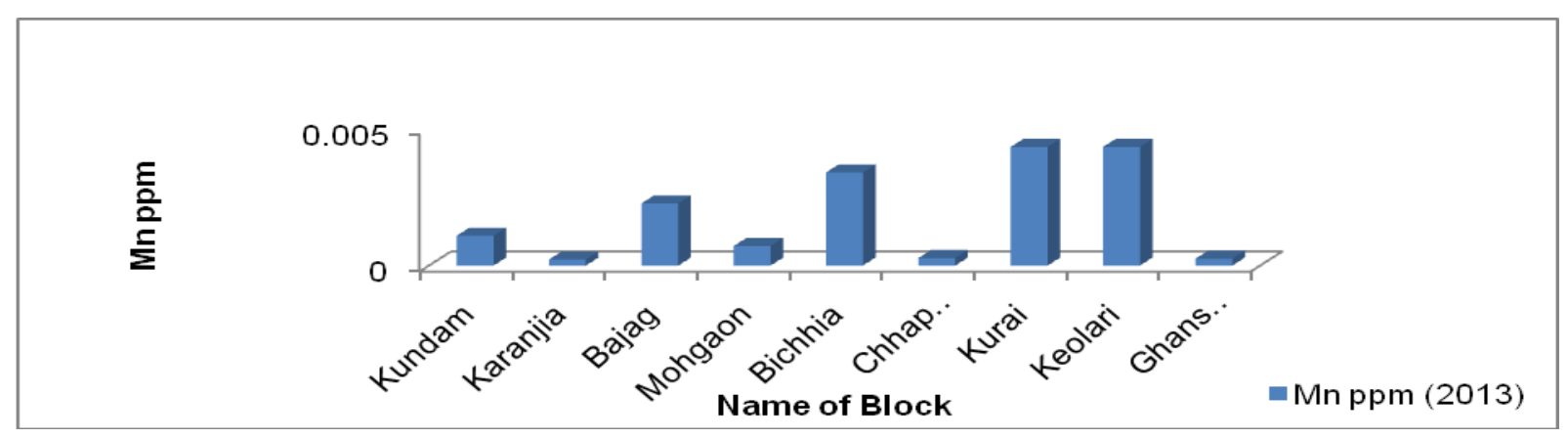


Fig.7 Block wise concentration of $\mathrm{Pb}$ - present values

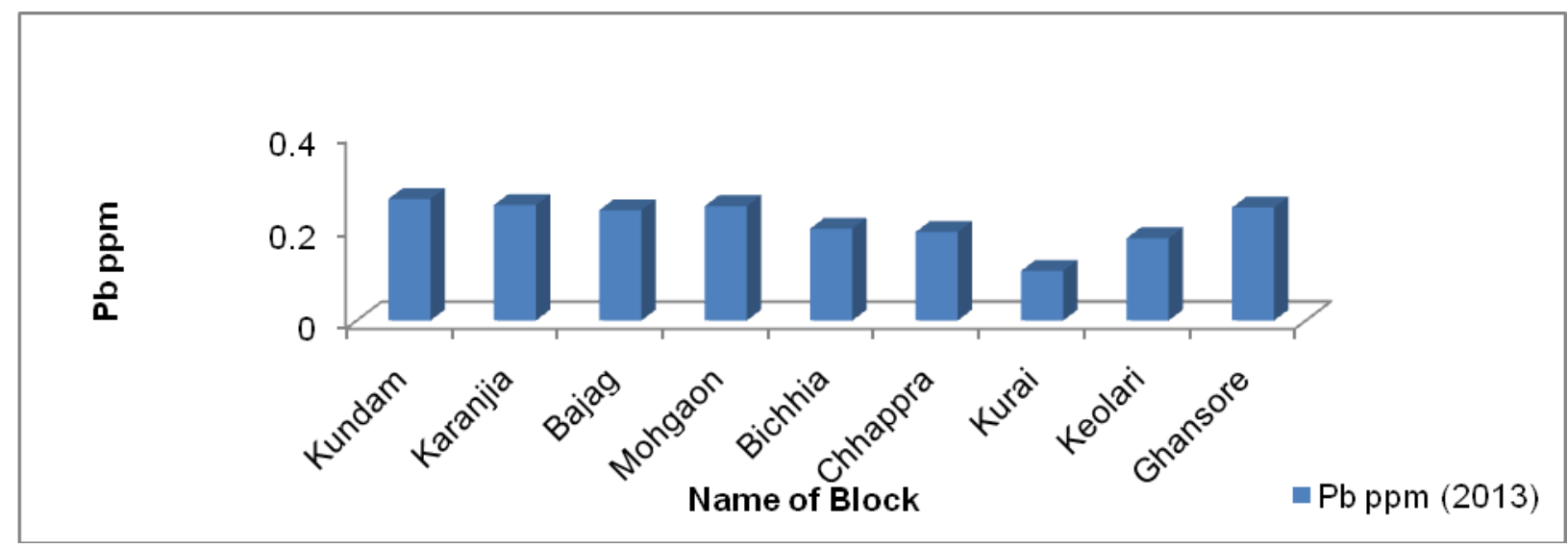

Manganese is essential plant nutrient but is toxic when its concentration is exceeding 0.2 ppm (Ayers and Westcot, 1985). The desirable limit for manganese is $0.1 \mathrm{ppm}$ and the permissible limit in the absence of alternate source is $0.4 \mathrm{ppm}$. Beyond this limit taste and appearance are affected and has the adverse effect on domestic uses and water supply structures. Toxic to a number of crops at a few tenths to a few ppm in acid soils (Rowe and Abdel-Magid, 1995). During the observation period concentration of manganese was found below the desirable limit, even very low amount of manganese was observed in all blocks of ground water samples in Figure 6.

The maximum limit for Lead is $0.1 \mathrm{ppm}$ as per the Royal Irrigation Department. And according to FAO recommendation for Irrigation water is $2.0 \mathrm{ppm}$. It inhibits plant cell growth if the concentration of lead is high. Lead is very harmful for human body, and its little amount is enough to damage nervous system of human body. During the observation concentration of $\mathrm{Pb}$ was found little more than the maximum recommended limit in all blocks, except Kurai block as shown in Figure 7.

Through a survey; Dindori, Mandla, Seoni, and Jabalpur districts the water quality was assessed and found that the concentration of minor constituent like $\mathrm{Zn}, \mathrm{Cu}, \mathrm{Pb}, \mathrm{Cr}, \mathrm{Cd}$, Ni and $\mathrm{Mn}$ is under the safe limit.

Trace element like $\mathrm{Ni}, \mathrm{Mn}$ and $\mathrm{Zn}$ etc., are micro plant nutrients these are beneficial for crops. In this study, these entire elements were found within desirable limit.

\section{Acknowledgement}

The author wish to thank Dr. M.K. Awasthi for his kind guidance and suggestions in the preparation of the manuscript. This work was supported in part by Collage of Agricultural Engineering Jawaharalal Nehru Krishi Vishwavidyala Jabalpur, Madhya Pradesh.

\section{References}

APHA, 1985. Standards methods for the examination of water and waste-water, $16^{\text {th }}$ edn.Ayers, R.S and West D.W. Cot. 1985. Water quality for agriculture, FAO irrigation and Drainage Paper 29.FAO Rome.

Ayers, R.S and West D.W. Cot. 1985. Water quality for agriculture, FAO irrigation and Drainage Paper 29.FAO Rome.

Bartram J., and Balance, R. 1996. Water quality monitoring - a practical guide to the design and implementation of freshwater quality studies and monitoring programme. 
Geneva: UNEP and WHO.

Cui, Y.J., Y.G. Zhu, R.H. Zhai, D.Y. Chen, Y.Z. Huang, Y. Qui and J.Z. Liang. 2004. Transfer of metals from near a smelter in Nanning, China. Environmental International 30: 785-791.

Dixit, A., and Shrivastava S. 2013. Assessment of Parameters of Water Quality Analysis of Hanumantal and Robertson Lake at Jabalpur (M.P.).Asian J. Research Chem. 6(8): August 2013.

Eriyamremu, G.E., S.O. Asagba, A. Akpoborie and S.I. Ojeaburu. 2005. Evaluation of lead and cadmium levels in some commonly consumed vegetables in the Niger-Delta oil area of Nigeria. Bulletin of Environmental Contamination and Toxicology 75: 278283.

Hassan A.S.S., Ghorade I.B. and Patil S.S., 2013. Role of Major and Minor Constituents in Ground Water Quality of Industrial Area, Aurangabad. M.S. India. Indian Journal of Applied Research. Volume: 3, Issue: 5, May 2013.

Hirsch R.M., Alexander R.B. and Smith R.A., 1991. Selection of methods for the detection and estimation of trends in water quality, Water resources research, 27(5), 803-813

Kumar A., 2004. Water Pollution. Nisha Enterprises, New Delhi.

Marshall, F.M., J. Holden, C. Ghose, B. Chisala, E. Kapungwe, J. Volk, M. Agrawal, R. Agrawal, R.K. Sharma and R.P. Singh. 2007. Contaminated Irrigation Water and Food Safety for the Urban and Periurban Poor: Appropriate Measures for Monitoring and Control from Field Research in India and Zambia. Inspection Report DFID Enkar R8160, SPRU, University of Sussex. www.pollutionandfood. net 2007.

Muchuweti, M., J.W. Birkett, E. Chinyanga, R. Zvauya, M.D. Scrimshaw and J.N. Lester.
2006. Heavy metal content of vegetables irrigated with mixture of waste water and sewage sludge in Zimbabwe: implications for human health. Agriculture, Ecosystem and Environment 112: 41-48.

Radhakrishan R., et al., 2007. A comparative study on the physicochemical and bacterial analysis of drinking borewell and sewage water in the three different places of Sivakasi. Journal of Environment and Biology, 28(1): 105.

Satarug, S., M.R. Haswell-Elkins and M.R. Moore. 2000. Safe levels of cadmium intake to prevent renal toxicity of human subjects. British Journal of Nutrition 84: 791-802.

Sharma, R. K., M. Agrawal and F. M. Marshall. 2007. Heavy metals contamination of soil and vegetables in suburban areas of Varanasi, India. Ecotoxicology and Environmental Safety 66: 258-266.

Sharma, R.K., M. Agrawal and F.M. Marshall. 2006. Heavy metals contamination in vegetables grown in waste water irrigated areas of Varanasi, India. Bulletin of Environmental Contamination and Toxicology 77: 311-318.

Smitha, P.G. et al., Physico-chemical characteristics of water samples of Bantwal Taluk, south-western Karnataka, India. J. Environ. Bio, 28(3) (2007) 591.

Tatawat R. K. et al., A hydrochemical profile for assessing the groundwater quality of Jaipur City. Environ. Monit. Assess, 143, (2008) 337.

Yadav S.S and Rajesh Kumar 2010. Assessment of Physico-Chemical Status of Ground Water taken from Four Blocks (Suar, Milak, Bilaspur, Shahabad) of Rampur district, Uttar Pradesh, India. http://www.rasayanjournal.com. Vol.3, No.3 (2010), 589-596.

\section{How to cite this article:}

Satyendra Thakur, M.K. Awasthi, R.K. Nema and Sarita Dubey. 2018. Role of Trace Constituent in Ground Water Quality in Nine Tribal Block of Madhya Pradesh. Int.J.Curr.Microbiol.App.Sci. 7(01): 2381-2386. doi: https://doi.org/10.20546/ijcmas.2018.701.286 